\title{
Cornel Zwierlein, L'importance de la Confessio de Magdebourg (1550) pour le Calvinisme: un mythe historiographique?
}

\section{Filippo Fonio}

\section{(2) OpenEdition \\ Journals}

Edizione digitale

URL: http://journals.openedition.org/studifrancesi/30071

DOI: $10.4000 /$ studifrancesi.30071

ISSN: 2421-5856

\section{Editore}

Rosenberg \& Sellier

\section{Edizione cartacea}

Data di pubblicazione: 1 avril 2006

Paginazione: 141

ISSN: 0039-2944

\section{Notizia bibliografica digitale}

Filippo Fonio, «Cornel Zwierlein, L'importance de la Confessio de Magdebourg (1550) pour le Calvinisme: un mythe historiographique?», Studi Francesi [Online], 148 (XLX | I) | 2006, online dal 30 novembre 2015, consultato il 19 avril 2021. URL: http://journals.openedition.org/studifrancesi/30071 ; DOI: https:// doi.org/10.4000/studifrancesi.30071

Questo documento è stato generato automaticamente il 19 avril 2021.

\section{cc) $($ ) $\ominus$}

Studi Francesi è distribuita con Licenza Creative Commons Attribuzione - Non commerciale - Non opere derivate 4.0 Internazionale. 
Cornel Zwierlein, L'importance de la Confessio de Magdebourg (1550) pour le Calvinisme: un mythe historiographique?

Filippo Fonio 


\section{NOTIZIA}

CORNEL ZWIERLEIN, L'importance de la Confessio de Magdebourg (1550) pour le Calvinisme: un mythe historiographique?, «Bibliothèque d'Humanisme et Renaissance», LXVII, 1 (2005), pp. 27-46.

Un'analisi delle fonti impiegate da Théodore de Bèze per compilare le opere del periodo 1560-1574 (prendendo dunque come terminus ad quem il Du droit des magistrats) porta lo studioso a ridimensionare il ruolo della Confessio et Apologia pastorum \& reliquorum ministrorum Ecclesiae Magdeburgensis rispetto alla diffusione in area calvinista del concetto di legittima resistenza del magistrato inferiore nei confronti del superiore reputato eretico. Riprendendo e in parte reinterpretando i dati raccolti da Robert Kingdon a cavallo degli anni Cinquanta nei suoi studi in merito al côté politico del pensiero di Bèze, Zwierlein individua in Bucer e Sleidan le probabili influenze del ginevrino per quanto riguarda la questione della tolleranza e della punibilità degli eretici. L'influenza della Confessio sulla formulazione della resistenza legittima da parte di Bèze (che sarà una delle basi della riflessione in merito alla monarcomachia) sarebbe indiretta, ferme restando anche le dinamiche della circolazione libraria, e l'accostamento fra le due posizioni é una mistificazione storiografica, tesa a individuare nella confessione luterana un'accentuata componente passiva, legittimista e antimoderna. 